\title{
La ausencia de Neruda y las ausencias de Neruda. Dos notas sobre el leer poético, la música y el olvido
}

\author{
The absence of Neruda and Neruda's absences. \\ Two notes on reading poetry, music and forgetting ${ }^{\prime}$
}

\author{
JUAN CARLOS RODRÍGUEZ \\ Universidad de Granada \\ España \\ jcrodri@ugr.es
}

\begin{abstract}
¿Se lee poco -y mal- la poesía? Evidentemente su recepción no suele ser masiva (salvo en el caso de la poética rockera, etc.) ni tampoco la poesía necesita ese requisito. Pero quizá haya momentos en que se descubre la ausencia de alguien en el canon de los grandes poetas contemporáneos. Alguien que hasta hace poco sí estaba allí, en ese El cartero (y Pablo Neruda) llevó a muchos lectores/as "nuevos" a preguntarse por la obra de aquel personaje que aparecía en el film explicándole al "cartero", junto al mar, lo que era una metáfora.

Intentaremos, pues, acercarnos brevemente a aquel personaje a través de dos notas que recogen algunos aspectos muy significativos de su vida y su obra. Son sólo eso, dos notas, para una aproximación -e incitación- a la lectura nerudiana.
\end{abstract}

\section{I}

\section{Primera nota}

Neruda: Búsqueda (y pérdida) del Unicornio Narval

Quizá algunas de las más bellas páginas escritas por Neruda se hallen en el texto titulado "Oceanografía dispersa", que se publicó por primera vez en la revista Vistazo de Santiago de Chile el 2r de septiembre de 1952. En esas líneas se nos cuenta uno de los múltiples regresos del poeta a su país, en un barco que atraviesa mares y océanos y, aparte de su fascinación por el mar, se intercala un recuerdo vivísimo: cómo en Dinamarca en una tienda de "historia natural" -de las que tanto amaba y que no hay, añade, en "nuestra América”- Neruda había encontrado por fin el unicornio: tres o cuatro cuernos de Narval, un pez que efectivamente existe en las aguas danesas. Armado con uno de esos cuernos se dedicó a alancear molinos ante la perplejidad del dueño de la tienda. Por fin sólo pudo comprar uno pequeño, casi de Narval recién nacido, se lo llevó a su pensión de Suiza,

\footnotetext{
${ }^{\text {I }}$ Para citar este artículo: Rodríguez, Juan Carlos. La ausencia de Neruda y las ausencias de Neruda. Dos notas sobre el leer poético, la música y el olvido. Alabe 5, junio 20I2 [http://www.ual.es/alabe]
} 
abrió la maleta para comprobar que de verdad allí estaba su unicornio, y de pronto, en el barco: "ahora no lo encuentro". ¿Lo habría perdido en la pensión suiza de Vésenaz, en algún cajón o bajo la cama? ¿O el unicornio habría regresado de forma misteriosa al círculo polar? Llegará la noche sobre el mar, termina el texto, y: “esconderá una vez más el gran palacio verde del misterio".

Siempre me ha fascinado este magnífico poema en prosa no sólo porque es una pequeña joya en sí mismo sino porque creo que en él se hallan condensadas casi todas las claves poéticas de un Neruda que hacía ya seis años (desde I946) había "legalizado" oficialmente su nombre -Pablo Neruda y no Neftalí Reyes- ante la administración chilena. Oficializar su nombre "poético" no carece de importancia. Públicamente quería transformar su historia y la de todos, y quería hacerlo siendo conocido -y reconocido- como lo que realmente él se consideraba: poeta total o totalmente poeta. Otro mito ya a punto de desaparecer a mitad del siglo XX y en los momentos más gélidos de la insufrible "Guerra fría". Un mito -el del poeta total- que se iba desvaneciendo tras la lenta agonía de las vanguardias y el final apocalíptico -con la bomba atómica- de la $2^{\text {a }}$ guerra mundial en 1945 . Y es sintomático: Neruda creyó en ese mito, lo necesitó para vivir y -casi increíblementelogró vivir "en y del” mito, de su poesía y de su escritura -siempre poética- a lo largo de su vida. Hasta sus casas fueron "poéticas", tanto la de Valparaíso como la fabulosa de Isla Negra, las dos saqueadas por los pinochetistas tras el golpe de estado del II de septiembre de 1973 (Neruda murió I5 días después de que Allende fuera asesinado en la Casa de la Moneda, la residencia presidencial chilena). Dos años antes, en el 7I, se le había concedido el Nobel con treinta libros a sus espaldas, desde Crepusculario a Las piedras del cielo (luego publicaría dos más y reelaboraría, de modo irregular, sus Memorias: de la edición póstuma, Confieso que he vivido, me gusta más el título que el texto). Y después la sombra pareció descender sobre él. ¿Qué pasó con la poesía de Neruda?

El primer diagnóstico es obvio: pasó que el mito de la poesía como expresión total de la vida y el mito de la revolución rusa y su posterior versión podrida del "estalinismo" (o del "socialismo real?": que eso se haya identificado con "comunismo" resultó fatídico, pero es un hecho), se estaban yendo al garete. Eran dos naufragios. La posmodernidad norteamericana y su mímesis europea de los años 80 y 90 arrancarían hasta la última astilla de aquellos dos barcos arrumbados en el fondo de todos los mares. El unicornio, efectivamente, parecía haber desaparecido en las aguas del círculo polar. Pero es que la posmodernidad se llevó también nuestro viejo mundo y nuestros lenguajes se habían quedado inertes, inservibles incluso ante palabras claves como libertad o democracia. El nuevo discurso del capitalismo globalizador nos dejaba inermes, mudos en la nueva realidad flotante e "imperial". Si, como indica -más mal que bien- el analista Jorge Alemán, el nuevo discurso capitalista consiste en la "apropiación particular del goce" -diríamos: la soledad y la expropiación de "lo común"- ocurrió lo inevitable: nadie sabía de lo que hablaba -cuando hablaba y si es que hablaba- e incluso el encanallamiento entre pureza y compromiso en poesía se había arrojado a los desvanes inútiles, al igual que la filosofía y la política. El siglo XX se había hecho muy corto, como señaló el historiador británico 
Hobsbawm. Y el propio Neruda lo definió así: “Siempre fue una agonía: / siempre estaba muriéndose:/ amanecía con la luz y en la tarde era sangre:/ llovía en la mañana, por la tarde lloraba". Y un poco antes: "Pero lo cierto/ es que no lo vivimos/ de tanto que queríamos vivirlo". Cuando el siglo XX se fue, hacía tiempo que todos nos habíamos quedado sin lenguajes. Sólo quedaba el de la explotación diaria del yo y a partir de ahí tuvimos que reinventarnos incluso nuestras lecturas de Neruda. Jamás olvidaré las noches paseando por calles solitarias y construyendo mi inevitable melancolía adolescente con los Veinte poemas de amor...: "y te pareces a la palabra melancolía". ¿Nosotros, los de entonces, en qué no éramos ya los mismos? Otra dosis de diagnóstico sobre la lectura de Neruda hoy: no es sólo que la literatura -o al menos nuestra cultura literaria- esté agonizando, es que está agonizando, repito, nuestra imagen del "yo" y del "lenguaje”. No se trata sólo, como decía Adorno en los viejos tiempos, de que la poesía -o la estética negativa- fueran la última guarida frente a la cosificación tecnocrática del sistema (curioso: Adorno hablaba casi como Heidegger tratando de atacar a Heidegger). Adorno -y sus seguidores posmodernos- aún se aferraba incluso al yo íntimo y privado, etc. En el año I979 ya llamé a esa supuesta cueva del "yo" la guarida inútil (en el prólogo a un libro de poemas de Álvaro Salvador). Hace muy poco, en Davos (Suiza), en la reunión del Fondo Económico Internacional, se ha planteado la cuestión del "Yo, sociedad anónima”, el “Me, Inc.”. Ese sería -se dijo allí- el nuevo narcisismo freudiano. Dejándonos de palabrerías, se trataba de constatar un hecho también señalado por F. Jameson hace años: el nuevo lenguaje tecnológico/global no es algo en sí mismo; es el resultado de un capitalismo que necesita construir nuestro "yo" como mero dispositivo/ mercancía, como simple efecto de resultados económico/ vitales. Esa es la realidad de nuestro "yo-soy-histórico" actual, vital. En este sentido el mundo poético de Neruda, el genio de las Odas elementales, el que creó aquel poema inolvidable sobre el caldillo del congrio (no una receta de cocina dentro de un poema, sino un poema sobre cómo hacer la vida con las manos), todo eso parecía estar muerto. Más claves de diagnosis: Neruda siempre intentó ser un poeta cósmico, circular y planetario, no ya sólo como Rubén o Withman (cuyo retrato presidía sus casas) sino abarcador de todo al modo homérico. Si El hondero entusiasta (1923) le resultó un fiasco porque el poeta uruguayo Carlos Sabat Ercasty le dijo que había mucho de Sabat Ercasty en aquel libro; si se "redujo" - son términos suyos- para escribir los Veinte poemas de amor y una canción desesperada; si Residencia en la tierra indica que la experiencia oriental en Rangoon (casi como El cónsul honorario de Graham Greene) le enseñó que el amor a la vida está siempre opacado por la muerte; si "Alturas de Machupichu” y el resto del Canto general es, en efecto, la epopeya casi homérica de la América "suya", algo escrito con diccionarios e Historias de América encontradas de casa en casa mientras huía de la policía; si Los versos del capitán salieron anónimos porque aún no podía hacer explícita su relación con Matilde Urrutia; si todo esto es así, yo aconsejaría leer hoy a Neruda empezando por el final: desde Memorial de Isla Negra (I964) a Fin de Mundo (I969). Es quizá ahí, al repasar su vida, cuando Neruda comprende que sus verbos básicos (germinar, fructificar, transformar) eran acaso ya el unicornio perdido. Ahora, 
sintomáticamente, sólo parecía existir el anterior verbo impersonal, el sucede ("Sucede que me canso de ser hombre", había escrito en Residencia..., siguiendo a Vallejo). La dialéctica entre Naturaleza e Historia (el eje de su poesía) semejaba así un sueño perdido: sólo quedaba hacer un Memorial de esa dialéctica, hablar del Fin de un Mundo y pedirle a las piedras que lo esperasen. Él intuyó lo que se nos venía encima. Un mundo en el que -para bien y/o para mal- probablemente ya no existirían historias de amor como las de su amante birmana Josie Bliss (otros versos memorables), ya no habría melancolía, ni spleen, ni ennui, ni noia. Sólo el “Me, Inc.”. Hace apenas 5 años una inteligente alumna norteamericana me comentó que el poema 20 era un ejemplo típico de un "ligue de verano" en California. Temí que añadiera que el caldillo del congrio lo hacían mejor en los Mc Donald's. No eran sólo banalidades sino síntomas del nuevo lenguaje inconsciente. Una nueva "hegemonía" - sin aparente alternativa- que ya conocíamos de sobra. Pero daba igual. Volví a releerme las Odas elementales y "sucedió” que los verbos germinar, fructificar y transformar cobraban otra vez sentido ante mis ojos porque también la vida seguía viva en esas páginas. ¿Sería posible aún encontrar un Narval?

\section{II \\ Segunda nota \\ Neruda y el tango del viudo}

I.- En la cubierta de la traducción italiana de las poesías de Neruda, una traducción magnífica de Salvatore Quasimodo, aparecían diversos dibujos que pretendían "ilustrar" el texto ya desde afuera: una hoz y un martillo tratando de luchar contra la inmensa serpiente que les atacaba; un hombre solitario en una habitación oscura; una Torre Eiffel rodeada de globos o flores y, bajo ella, una pareja bailando. La postura y la posición de las piernas de la mujer y del hombre trataban obviamente de imitar una "cortada" o cualquier otra figura tanguera. Eran obviamente cuatro símbolos plausibles de la poética nerudiana y a partir de ellos vamos a entrar en la cuestión concreta que nos interesa. Es decir, en la relación entre Neruda y el Tango. Siempre he defendido a los poetas del tango, a los letristas clásicos desde Contursi o Cadímaco al "Negro Cele" y Homero Mazi y, por supuesto, Discépolo. Es sintomático cómo cambian las perspectivas. Cuando publiqué mi ensayo sobre el tango, allá por los principios de los años 8o, rastreé prácticamente en todos los diccionarios y antologías de poesía argentina y no aparecía ni un solo autor "tanguero". Hoy, por el contrario, es rara la antología donde Discépolo o Manzi no aparezcan. Es verdad que los tanguistas clásicos eran poetas con música y con una tremenda influencia de Rubén Darío y de los diversos vaivenes del Modernismo más o menos populista, desde Evaristo Carriego a Lugones, que no podía soportar el tango. Pero hay evidentemente poemas "tangueros" que se sostienen por sí solos, con música de sí mismos: no hace falta citar a Malena de Manzi ("tus ojos son oscuros como el olvido/ tus labios apretados como el rencor”) o Cafetín de Buenos Aires de Discépolo, con aquellos versos increíbles: 
"yo aprendí filosofía, dados, timba/ y la poesía cruel de no pensar más en mí". Lo que quiero decir es esto: hay poemas "tangueros" que no necesitan música. Como señaló el extraordinario poeta portugués Fernando Pessoa: "Esto es la poesía: cantar sin música; por eso los grandes poetas no son musicales [...] ¿Cómo lo van a ser si son músicos?”. Esto es: la verdadera poesía genera su propia música interna. Volveremos sobre esta frase porque nos va a llevar muy lejos: a los poetas del tango sin música y -sobre todo- a la ética/ estética del tango. Lo podremos ver en Borges, en Cortázar, en Gil de Biedma o en Neruda. Pero hagamos un inciso obvio: hay que tener en cuenta que en gran medida el tango se desgajó de la milonga del XIX y que milonga significaba "palabra” entre los esclavos negros brasileños. Sin embargo el tango fue durante años un baile sin letra. Se puede afirmar que el primer gran letrista del tango fue Pascual Contursi y que el primer tango que grabó Gardel fue "Mi noche triste” del propio Contursi, en I9I7. La Milonga la rehicieron Manzi y Piana en I93I con su "Milonga sentimental”. Aunque es evidente que Gardel y Piazzola mezclaron muchas veces el tango con la milonga rural o urbana. Ahora bien: si se puede hablar de tango sin música y de tango sin letra, generalmente conviene que en el tango la música y la letra sean inseparables, puesto que el tango es en efecto "un pensamiento triste que se baila”, por recurrir a otra frase célebre de Discépolo. El tango -dije alguna vez en sentido spinoziano- es una expresión de afecciones del cuerpo y de la mente, "afecciones" que se condicionan en un mutuo vaivén continuo. Y resulta curioso, en este sentido, que continuamente se realicen homenajes al que parece el elemento decisivo de la música del tango. Es decir, al bandoneón que llegó relativamente tarde al tango, tanto que Gardel se negó siempre a cantar con bandoneón, incluso cuando cantaba -y esto es el colmo- su famoso "Bandoneón arrabalero/ viejo fuelle desinflado/ te encontré como a un pebete/ que la madre abandonó...”, prefería cantarlo sólo con guitarras. Sólo una excepción: en el cine Gardel sí cantó con bandoneón Tomo y obligo. Pero lo que nos importa: ¿Qué relación tuvo Neruda con la ética/ estética del tango? Creo que la explicación resulta a la vez compleja y sencilla. Tanto como las dos imágenes contradictorias que nos ofrece Borges: por un lado Borges nos dice que el tango es inconcebible fuera del Río de la Plata; por otro lado Borges nos dice que la literatura argentina es tan mala que sólo se convertirán en "universales" los letristas de tango. Son dos exageraciones, claro, pero hay un fondo de verdad en ambas frases: el tango nació en medio del desarraigo de los inmigrantes argentinos; el tango pareció desaparecer cuando los nacionalismos ya eran inútiles -en la primera globalización- y cuando los milicos torturadores exprimieron su nacionalismo hasta hundirse en la guerra de las Malvinas. Claro que intervinieron factores de gusto y negocios musicales por en medio. Y por supuesto que hubo un momento en que esa crisis de los 6o-7o pareció prolongarse cuando la realidad acorraló en los años go a la burguesía argentina y la burguesía argentina se vio atrapada no en el diván psicoanalista sino en el "corralito" bancario. Pero el tango sobrevivió por lo que Osvaldo Pugliese solía decir: porque el tango era verdad, pero era verdad no sólo en tanto que porteño sino en tanto que arrastraba otra verdad más profunda por debajo. La verdad del desarraigo y la explotación. Esa es la verdad de fondo del tango y por eso el tango es del 
cuerpo y es seco, duro, rencoroso y con unas notas de humor o de sátira cuando intenta desbordarse en melodrama o en sentimentalismo excesivo. Cuando un pensamiento triste se baila, o se hace cuerpo vivo, lo trágico y lo cómico se mezclan, se desnudan como en cualquier amor o pasión, y de ahí nace su poesía cruel, su rencor y su dolor, su alegría y su amargura triste o dulce, incluso autoirónica y autodestructiva. Gil de Biedma escribió: "La mejor poesía/ es el verbo hecho tango".

Y también de ahí nace, de esa ética/ estética del desarraigo y del deshacerse, lo que podemos llamar la poética del tango, algo que se inscribe por supuesto en los tangos sin música. Por ejemplo: si alguna vez indiqué que El amor en los tiempos del cólera de García Márquez era el mejor bolero que se haya escrito nunca (y en cierto modo Gabo nos cuenta en ese libro la historia imposible del casi imposible amor de sus padres), igualmente se ha dicho que Rayuela es un tango de más de seiscientas páginas. Un tango, este de Rayuela, que cuenta el segundo verdadero nacimiento del tango: en París, la ciudad mítica del exotismo y las vanguardias, que también relanzó a la música negra, el jazz que adoraba Cortázar, la otra música exótica y no menos desarraigada y legendaria, ese jazz casi tanguero que Cortázar supo plasmar en otra obra magistral, el cuento Elperseguidor. Con más síntomas aún: si desarraigadas y lorquianas son algunas letras de Homero Manzi - a fin de cuentas un profesor de literatura- con su Sur mítico (como el igualmente mítico Sur de los arrabales y los gauchos de Borges), convendría recordar acaso que no menos lorquianas y tangueras son las dos obras maestras de la Copla española: Ojos verdes es Lorca puro, pero Tatuaje es un tango inigualable: "Y entre dos copas de aguardiente/ sobre el manchado mostrador..."

2.- Piazzola le puso música a algunos poemas de Borges, y Cortázar le puso letra a ese tango infinito de hombre y mujeres deshechos y rehaciéndose que es Rayuela. Y con ello llegamos al núcleo central de nuestro planteamiento. Pues en efecto: mucho antes, en torno a I928, Neruda había escrito el Tango delviudo. La historia es quizá suficientemente conocida pero a mí me parece de una imaginación real asombrosa. Hacia r925 Neruda empezó a plantearse alguna forma de ganarse la vida en serio. El joven estudiante -escritor sin estudiar-, hermosamente anarquista como todos los colaboradores bohemios de la revista Claridad, tenía ya varios libros publicados y otros publicándose: Crepusculario (1923), Veinte poemas de amor... (1924), Tentativa del hombre infinito, Anillos y ElHabitante y su esperanza (los tres del 26), más El hondero entusiasta, indicábamos, guardado en el cajón hasta el 33. A este Neruda, pues, le había llegado ya la hora de la necesidad del dinero e incluso de salir de un Chile que le asfixiaba. La matanza de los obreros del salitre de la provincia de La Coruña de I925, la caída y la vuelta del presidente Alessandri, presagiaban la dictadura brutal de Carlos Ibáñez y la atmósfera chilena resultaba tosca y sucia. El joven venido de las tierras casi inexploradas del sur, de Parral y de Temuco, aquel mundo de piedra y madera, de frío y del ferrocarril en que trabajaba su padre (y por supuesto del vino: las Odas elementales terminan con una oda al vino, y adquieren así el sentido dionisiaco que las odas griegas tenían), a aquel joven del inesperado éxito 
de los Veinte poemas de amor, Santiago, la capital chilena, se le había quedado pequeña e irrespirable: "Estoy desesperado y aburrido de todo", le había escrito a su hermana Laura en esa época. Durante dos años visitó una y otra vez a un secretario de Asuntos Exteriores. El susodicho secretario era poético y esteta: siempre le hablaba de Tchaikovsky. Como sin embargo el puesto no llegaba nunca, Neruda le contó el caso a un amigo suyo, Bianchi, que sí había sido embajador y que le dijo lo obvio: vamos a ver al Ministro. Y en efecto el Ministro, muy bajito y nada esteta, que se sentaba sobre la mesa del despacho para parecer más alto, llamó al secretario estetay le exigió un puesto para Neruda. La cosa funcionó inmediatamente. Pero veamos cómo. Dando vueltas al mapa y a los papeles surgió un nombre: Rangoom. Neruda dijo: bien, ahí me voy. ¿Nos imaginamos la situación? ¿Quién sabía en aquel despacho, en Chile o en todo el mundo de la América latina o hispánica, dónde estaba Rangoom y qué era aquello? Pues el caso fue que en i927, mientras algunos poetas españoles viajaban a Sevilla (con lo que se iba a justificar luego la llamada Generación del 27), Pablo Neruda emprendía un casi interminable viaje hacia Rangoom, en Birmania. Se pasó cinco años en tierras orientales y regresó casado con una holandesa de Java, a la que iba a llamar la "giganta", casi como un recuerdo del poema de Baudelaire. Pero vayamos al principio de esta historia. ¿Qué podía hacer Neruda en Rangoom? Odiar a los ingleses que eran los que de verdad mandaban, beber mucho, fumar opio y cobrar poco y mal: no tenía sueldo fijo sino que sólo cobraba cuando firmaba "oficialmente", o sea, cuando algún barco chileno viajaba desde Rangoom con mercancías chinas o asiáticas en general. Y podían pasar meses sin que eso sucediera. La correspondencia con su amigo argentino Héctor Eandi es tremendamente reveladora al respecto. Allí empezó a tomar forma su libro más triste y ensimismado, Residencia en la tierra, ya significativo desde el título: en la tierra no se está de veras, se es un mero residente, un huésped en casa ajena. Sólo la muerte vale, pero mucho ojo, también vale la tierra, la materia. Sobre todo esa imagen ancestral de la madera, un símbolo de muerte -el ataúd- pero también de vida, la que estallará luego en las Odas elementales. Ya había escrito algunos poemas de "Residencia..." en Chile y el volumen final, la Tercera residencia, lo concluiría en España con un poema de hacia I934 dedicado a un recuerdo: el de Josie Bliss. ¿Quién era Josie Bliss? Dejemos que Neruda nos lo cuente:

...me enamoré de una nativa. Se vestía como una inglesa y su nombre en la calle era Josie Bliss, pero en la intimidad de su casa, que pronto compartí, se despojaba de aquellas prendas y de aquel nombre para usar su deslumbrante sarong y su nombre birmano...[más adelante] tuve dificultades en mi vida privada. La dulce Josie Bliss fue reconcentrándose y apasionándose hasta enfermar de celos. Tal vez yo hubiera continuado siempre junto a ella. Sentía ternura hacia sus pies desnudos, las blancas flores que brillaban sobre su cabellera oscura, pero su temperamento la llevaba hasta un paroxismo salvaje. Sin causa alguna tenía celos y aversión a las cartas que me llegaban de lejos, a los telegramas que me escondía, al aire que respiraba. A veces, de noche, me despertaba la luz encendida y creía ver una aparición detrás del mosquitero. Era ella, apenas vestida de blanco, blandiendo su largo cuchillo 
indígena, afilado como navaja de afeitar, paseando por horas alrededor de mi cama sin decidirse a matarme. Con eso, me decía, terminaría sus temores. Al día siguiente preparaba curiosos ritos para asegurar mi fidelidad.

Aparte del "Tango del viudo" y del poema final de Residencia en la tierra, hay otros cuatro poemas dedicados al recuerdo de Josie Bliss: dos en el libro Estravagario ("Regreso a una ciudad" y "La desdichada") y dos de la época final, de Memorial de Isla Negra (1964) titulados "Rangoom I927" y "Amores: Josie Bliss" (los otros amores oficiales de Neruda fueron, como se sabe, aparte de la ya citada holandesa Ma Antonieta Haagener, "Maruca", de la que tuvo su única hija, Malva María, que murió muy pronto, fueron la argentina Delia del Carril, a la que conoció en España en I934, cuando él era cónsul en Barcelona y el año siguiente en Madrid, y finalmente Matilde Urrutia). Por supuesto que de esa estancia consular hispánica surgiría un libro sobre la guerra España en el corazón y la ayuda al exilio republicano con el barco Winnipeg.

Pero leamos con un poco detenimiento este "Tango del viudo" de hacia I928:

\section{TANGO DEL VIUDO}

OH Maligna, ya habrás hallado la carta, ya habrás llorado de furia,

y habrás insultado el recuerdo de mi madre

llamándola perra podrida y madre de perros,

ya habrás bebido sola, solitaria, el té del atardecer

mirando mis viejos zapatos vacíos para siempre

y ya no podrás recordar mis enfermedades, mis sueños nocturnos, mis comidas,

sin maldecirme en voz alta como si estuviera allí aún

quejándome del trópico de los coolíes corringhis,

de las venenosas fiebres que me hicieron tanto daño

y de los espantosos ingleses que odio todavía.

Maligna, la verdad, qué noche tan grande, qué tierra tan sola!

He llegado otra vez a los dormitorios solitarios,

a almorzar en los restaurantes comida fría, y otra vez

tiro al suelo los pantalones y las camisas,

no hay perchas en mi habitación, ni retratos de nadie en las paredes.

Cuánta sombra de la que hay en mi alma daría por recobrarte,

y qué amenazadores me parecen los nombres de los meses,

y la palabra invierno qué sonido de tambor lúgubre tiene.

Enterrado junto al cocotero hallarás más tarde

el cuchillo que escondí allí por temor de que me mataras,

y ahora repentinamente quisiera oler su acero de cocina 
acostumbrado al peso de tu mano y al brillo de tu pie:

bajo la humedad de la tierra, entre las sordas raíces,

de los lenguajes humanos el pobre sólo sabría tu nombre,

y la espesa tierra no comprende tu nombre

hecho de impenetrables substancias divinas.

Así como me aflige pensar en el claro día de tus piernas

recostadas como detenidas y duras aguas solares,

y la golondrina que durmiendo y volando vive en tus ojos,

y el perro de furia que asilas en el corazón,

así también veo las muertes que están entre nosotros desde ahora,

y respiro en el aire la ceniza y lo destruido,

el largo, solitario espacio que me rodea para siempre.

Daría este viento del mar gigante por tu brusca respiración

oída en largas noches sin mezcla de olvido,

uniéndose a la atmósfera como el látigo a la piel del caballo.

Y por oírte orinar, en la oscuridad, en el fondo de la casa,

como vertiendo una miel delgada, trémula, argentina, obstinada,

cuántas veces entregaría este coro de sombras que poseo,

y el ruido de espadas inútiles que se oye en mi alma,

y la paloma de sangre que está solitaria en mi frente

llamando cosas desaparecidas, seres desaparecidos,

substancias extrañamente inseparables y perdidas.

Lo primero que nos restalla en la lectura es que a este poema de "amor fou", de locura, pasión, rencor, miedo, sexo y sensualidad corporal y vital, Neruda no tuviera más remedio que titularlo Tango. Y además un tango donde está presente, en toda su crudeza, no sólo la vida sino la muerte. Pues la dialéctica es clara: él se escapa de la chica birmana para salvar la vida; pero, al separarse, en esa huída, no es que se quede solo, sino mucho más radicalmente: se queda viudo. Al matar la relación no sólo ha tratado de borrarla a ella sino que de hecho se ha borrado a sí mismo. Veamos los núcleos básicos del poema.

Como en cualquier tango que se precie el poema comienza con un insulto que es más bien una descripción: Maligna, reforzada con una admiración: Oh Maligna. En realidad este primer núcleo del poema es una conjunción de dos adioses, de dos mundos que son el mismo: la fusión de atmósferas entre la imagen de la birmana maligna y del maligno Rangoom, la atmósfera pegajosa y cruel y de piel que en realidad nos deja traslucir una nostalgia irremediable. El poeta se marcha pero en el fondo sabe que ya no podrá marcharse nunca. Los elementos sígnicos del poema son fabulosos: la carta que le ha dejado a la chica como despedida, la furia de ella al leerla; cómo ella habrá insultado a otro elemento tanguero básico, a la “vieja”, a la madre de él, llamándola perra podrida 
y madre de perros, cómo ella notará la ausencia (la ausencia son los zapatos vacíos que él ha dejado en la huída: zapatos y huída suponen una correlación mamagnífica) pero a la vez, también, cómo la ausencia implica un oscuro negativo, una fotografía opaca, una cesura en la memoria: ella ya no podrá recordarlo, esto es, ya no podrá con-vivir nada de él (las enfermedades, las comidas, los sueños) sino maldiciéndolo en voz alta, recordándolo pues únicamente en sus desdichas cotidianas: cómo el poeta se quejaba del trópico, de las venenosas fiebres, de los coolíes, de los espantosos ingleses -y aquí la ausencia se convierte en presencia, en recuerdo presente para el propio poeta, pues añade: "los ingleses que odio todavía" -. Como indicábamos los ingleses eran aún el símbolo del primer colonialismo global y por eso los odiaba también César Vallejo, al que tanto admiró Pablo Neruda. Pero señalamos esto porque el segundo núcleo básico del poema es en estricto esta presencia presente del "viudo", su propia ausencia como muerte, un espacio donde todo parece estar muerto sin ella. Y por eso el diálogo del texto se vuelve más coloquial, más de tú a tú, reconociendo que la muerte vive allí a su lado y que si ella no está, todo está muerto:

"Maligna, la verdad, qué noche tan grande, qué tierra tan sola!"

Y es la propia soledad del viudo la que se nos narra de una manera cotidianamente implacable e impecable. Pues la soledad de aquellos viejos zapatos vacíos es un traslado desde el antes de conocerla a ella, al ahora de la nueva casa. ¿Cuál era ese antes? Muy fácil: la vida solitaria en Rangoom que ahora se reproduce. Son algunos de los mejores versos que escribió Neruda, subrayando el otra vez de aquel "antes de ella”, resaltando el desorden y el nadie. Fijémonos:

"He llegado otra vez a los dormitorios solitarios a almorzar en los restaurantes comida fría y otra vez tiro al suelo los pantalones y las camisas, no hay perchas en mi habitación ni retratos de nadie en las paredes."

Esa es la imagen del antes de ella, el otra vez volver al inicio, al antes de conocerla, ese es el tango del viudo. Y por eso aparece de inmediato -o irremediable- la nostalgia en el tercer núcleo temático. El "viudo" lo daría todo por volver a recobrarla, pues sin ella todo es invierno, sonido de tambor lúgubre, como el paso de los meses en la sombra del alma: "Cuánta sombra de la que hay en mi alma...”, etc.

Pero de repente aparece, tras esta nostalgia de ausencia total, otra sombra: la imagen del cuchillo. Y Neruda nos lo cuenta de nuevo con una ambigüedad que pasma. La estrofa traslada la dialéctica vida/ muerte (que a partir de la guerra de España se convertirá para Neruda en la dialéctica Historia/ Naturaleza), traslada esa dialéctica vida/muerte, digo, nada menos que al cuchillo mismo: las cosas sí viven, sí anhelan tener vida (como el 
cuchillo guardado que nos narra Borges). Este cuchillo lo había enterrado Neruda bajo el cocotero, está enterrado por miedo a que ella lo usara, y ahora a Neruda le duele ese entierro, sufre también por la ausencia del cuchillo, lo imagina en su prisión y en el deseo del cuchillo de su vuelta a la luz. Las imágenes son sorprendentes: el cuchillo -y el poeta- quisiera oler su acero de cocina, volver a la costumbre de la mano de ella, incluso del brillo de su piel. Y así los lenguajes se entreveran: bajo la tierra el cuchillo sólo sabía el nombre de la chica, el único lenguaje humano que podía recordar (el pobre llama Neruda al cuchillo) pero la tierra no puede comprender el nombre de ella. Un nombre -concluye la estrofa- "hecho de impenetrables substancias divinas", unas sustancias extrañas que conviene memorizar puesto que con ellas va a concluir también todo el poema.

El cuchillo es pues también materia viva, y con elementos naturales vivos: es así como el poeta nos cuenta cómo lo recuerda, cómo le aflige pensar en ella. Fijémonos de nuevo en ese sustrato de los signos: no piensa estrictamente en ella a través de sus piernas, de sus ojos o de su corazón, sino que piensa en el claro día de las piernas, esas piernas recostadas como duras aguas solares; no piensa estrictamente en sus ojos, sino en la golondrina que vive y vuela y duerme en esos ojos; no piensa estrictamente en el corazón pasional de ella, sino en el perro de furia que se asila en ese corazón. Así el ver del poeta, en esa ausencia oscura, es sólo un "ver” de muerte entre los cuerpos y el amor. Ahora el respirar del poeta es sólo de ceniza y de lo destruido, incluso el espacio que le rodea parece solitario para siempre. Por eso también la voz poética, como el cuchillo, quiere volver a vivir, quiere volver a la costumbre de ella. Lo daría todo, incluso el viento del mar, a cambio de aquella respiración de la mujer. Dos aires o dos vientos cruzados de nuevo. Oírla respirar en noches sin olvido, oír esa respiración que es como un látigo en la piel de un caballo. Y puesto que la respiración es tan sensual como esa piel de caballo, la sensualidad se extrema al límite en los dos versos quizá más célebres del poema: "Y por oírte orinar, en la oscuridad, en el fondo de la casa/ como vertiendo una miel delgada, trémula, argentina, obstinada”. Reconozco que lo que más me fascina -junto a ese tintinear de adjetivos que pretende reproducir el sonido de esa orina/ miel- lo que más me fascina, digo, es la doble distribución de los espacios. Una doble distribución que resulta increíble: por un lado la oscuridad de la casa y el fondo de la casa que compartieron. En esa oscuridad el poeta está solo unos momento y la oye en la distancia, allá lejos. Pero eso era antes. Ahora vuelve a oírla en el recuerdo, de nuevo solo y ya desde una distancia insalvable. Insisto en que ese doble juego de espacios resulta magistral, porque revela la oquedad absoluta del cuerpo y del alma del solitario: el coro de sombras que es lo único que posee, las espadas inútiles que hacen ruido en su alma. Fijémonos en que al igual que antes no nos ha hablado directamente de las piernas, de los ojos o del corazón de la chica, sino a través de esos signos intermediarios que recreaban su destello de vida, es decir, el claro día, las aguas duras, la golondrina y su vuelo o el perro de furia, ahora Neruda utiliza el mismo procedimiento para hablar de sí mismo: no sólo le daría su cuerpo y su alma para volver a ella, sino el coro de sombras o ese ruido de espadas inútiles que le atormentan. Incluso más: la paloma de sangre que está solitaria en su frente y que llama, que reclama a 
todas esas cosas y esos seres que eran ella, esas cosas y seres desaparecidos que formaban la sustancia de su nombre, las sustancias extrañamente fundidas en el nombre de ella, inseparables de ella y sin embargo -termina el poema de manera trágica- "inseparables y perdidas". Así acaba ese poema impresionante que es el "Tango del viudo". Con esas sustancias perdidas y condensadas en el nombre birmano de Josie Bliss que ignoraremos siempre y que parece un símbolo mágico de todo aquel extraño mundo oriental, que también ignoramos. Pero hay aún un corolario más, igualmente trágico y de escritura desgarrada. Neruda nos cuenta la historia concreta de su huida: había tenido la "suerte" de que el gobierno chileno lo enviara a Ceilán. Que se escapó en silencio de la casa, dejándolo todo, pero que en cuanto el barco empezó a navegar hacia su nuevo destino también él comenzó a escribir el "Tango del viudo". Y sin embargo, pronto aparece un segundo escenario: sin saber cómo, al cabo de un tiempo la chica lo localizó, alquiló una casa enfrente de la de Neruda y volvieron a vivir juntos. Salvo que todo seguía igual: Josie Bliss continuaba amenazando con matarlo, con quemarle la casa, incluso atacó con el cuchillo a una chica de la embajada inglesa que iba un día a visitarlo. Decidieron separase, y él la acompañó al barco que la devolvería a Rangoom. Cuando el barco iba a zarpar, allí, sobre el puente, ella comenzó a abrazarlo y a besarlo, llenándolo de lágrimas, hasta que de pronto se puso de rodillas y Neruda se quedó desconcertado. ¿Qué iba a hacer ella? Lo que hizo fue besarle los zapatos y mancharse la cara con la tiza con que Neruda se limpiaba sus zapatos blancos del trópico. Neruda lo cuenta así: "Mi corazón adquirió allí una cicatriz que no se ha borrado. Aquel dolor turbulento, aquellas lágrimas terribles rodando sobre el rostro enharinado, continúan en mi memoria”. (¿Recordamos, por nuestra parte, aquellos otros zapatos que Neruda había dejado abandonados en su huida de Rangoom?).

En verdad ignoro si el poema se ha musicado o, si no es así, por qué ninguno de los grandes músicos del tango (Troilo, el sublimador del tango clásico; o en especial Piazzola, el innovador del tango hasta convertirlo en música sin más) ninguno, digo, quiso armonizar este poema admirable. Quizá, como decíamos al principio, porque el poema lleva ya demasiada música dentro de sí mismo. Pero lo que resulta obvio, conociendo la historia, es la extraordinaria potencia poética de Neruda. Como apuntábamos, él comprendió de inmediato que aquella historia de amor loco sólo podía enmarcase y entenderse dentro de un espacio y un ámbito muy determinados: el espacio y el ámbito del tango. Y de ahí la genialidad de titularlo "Tango del viudo". Pero hay más: cuando después de la II guerra mundial, y en medio de la guerra fría, Neruda regresa a Rangoom descubre que veinte años sí son mucho, que no sólo la ciudad ha cambiado sino que sobre todo ha cambiado él mismo. Y así escribe los dos poemas que publicará en Estravagario y que curiosamente también llevan títulos casi tangueros: los aludidos "Regreso a una ciudad” y "La desdichada". En "Regreso a una ciudad" Neruda nos avisa de que es peligroso caminar hacia atrás porque de repente descubres que el pasado es una cárcel. Volver es inútil, y no sólo por la frente marchita sino porque la historia lo transforma todo, también a cada uno de nosotros. Por eso es mejor seguir hacia adelante. Ya lo escribió también Gil de Biedma (al que de vez en cuando convendría volver) en otro poema de tango sin música y literal y 
gardelianamente titulado "Volver": "Volver, pasados los años/ hacia la felicidad/ -para verse y recordar/ que yo también he cambiado".

Eso le sucedió a Neruda cuando regresó a la ciudad perdida y a la casa ya inexistente de aquel amor de locura y de tango. Aunque siempre queda la memoria. Neruda en el final del poema titulado "Rangoom I927", de Memorial de Isla Negra, dice sencillamente esto: "Yo y ella caminamos juntos a sumergirnos/ en el placer amargo de los desesperados”.

Desde luego es otra versión magnífica de un tango. Y con esa imagen podríamos decir que Neruda y el tango se quedaron así mano a mano. Incluso -si se me excusa la analogía- con el Cervantes del Primer Quijote que también salvó un poema de desesperanza absoluta en los versos del suicida Grisóstomo. Una Canción desdesperada, la cervantina que a Neruda le sirvió (muy plausiblemente) no sólo para concluir sus Veinte poemas de amor sino para contarnos este amor suicida que acabó entre el llanto y la tiza de unos zapatos entre Rangoom y Ceilán.

Dos pérdidas, pues, y dos ausencias irremediables: la pérdida del Narval en Suiza y la pérdida del amor imposible en el Oriente más lejano.

Al cabo de los años Neruda intentó recuperar la nostalgia (el duelo) de ambas ausencias, de ambas pérdidas inolvidables para él. Lo que me temo mucho es que ya resultara irreparable para nosotros la pérdida de Neruda y de tantos otros como él (el propio Huidobro, por ejemplo): As time goes by...

La historia (no gratuitamente) va eligiendo a sus ausentes, como se deshace el humo con el viento. Quizá sólo quede el caldillo del congrio, puesto que la crítica literaria (la del "me gusta/ no me gusta") acostumbra a seguir siendo bastante culinaria: nos enseña a comer pero no a leer. Y quizá también esto resulte lógico, pues a fin de cuentas así tendremos una mejor digestión moral. Esto me gusta o no me gusta porque esto es bueno o malo. O más en estricto una digestión museística: este es sólo válido para el museo arqueológico, mientras que esto sí que es bueno porque es nuevo y sirve para la pasarela fashion. El mismo Valèry creó su propio Comentario marino, un sitio donde el mar no recomienza más que en su superficie: abajo yacen los restos del Narval. 